\title{
Autobiografinen opettajatutkimus ottaa ja antaa
}

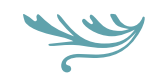

AUTOBIOGRAFINEN TUTKIMUSTAPA on suotta jäänyt syrjään, vaikka narratiivinen eli kerronnallinen tutkimus, mukaan luettuna elämäkertojen tutkimus, on lisääntynyt tiedemaailmassa. Haasteellisuudestaan huolimatta lähestymistapa on varteenotettava vaihtoehto.

Käsittelemme puheenvuorossamme tutkimustapaa, jota kutsumme autobiografiseksi eli omaelämäkerralliseksi opettajatutkimukseksi. Pyrimme tekemään omaelämäkerrallisen opettajatutkimuksen tutuksi muillekin tutkijoille. Sen vuoksi olemme parin viime vuoden aikana käyneet kahdenkeskisiä keskusteluita, ja olemme yhteisten tekstien (Johnson \& Kivioja 2016) ja konferenssiesitysten muodossa verranneet kokemuksiamme omaelämäkerrallisesta opettajatutkimuksesta.

Käsitteiden, tietoteoreettisten kysymysten ja analyysitapojen ohella olemme pohtineet omaelämäkerrallisen tutkimuksen laatu- ja luotettavuuskysymyksiä. Olemme kirjoittaneet ja puhuneet siitä, millaisten vaiheiden kautta päädyimme tutkimustapaan, millaisia pulmia kohtasimme sen soveltamisessa ja mitä lopulta katsomme oppineemme tutkimustavasta. Samanlaisista kokemuksista huolimatta yhteinen käsityksemme tutkimustavasta tuo esiin erilaisuutta ja erilaisia tulkintoja. Ehyttä ja aukotonta synteesiä on vaikea saavuttaa, emmekä ole sitä tavoitelleetkaan.

\section{KOKEMUKSIA JÄLJITTÄMÄSSÄ}

Kasvatuksen tutkimus on pohjimmiltaan kokemuksen tutkimista. Kokemus sitoutuu aikaan ja paikkaan, ja se saa tarinan muodon. Kokemus hahmottuu tarinoissa, joita ihmiset elävät. Tarinat ovat ajattelun, tietämisen ja kulttuurisen ymmärtämisen perusvälineitä. Opettajan ammatilliseen kehittymiseen oleellisesti kytkeytyen kasvatus, opettaminen ja oppiminen voidaan nähdä yksilöllisten ja yhteisöllisten tarinoiden konstruointina ja uudelleenkonstruointina (Syrjälä 2015).

Kerronnallisuutta korostavassa yhteiskunnassamme on vahvistunut käsitys, että tarinoita "saa keräämällä". Näin sanotaan monissa metodioppaissakin. Tutkimustavan periaate voi tässä valossa tuntua yksinkertaiselta: henkilö kertoo ne asiat, jotka hän on nähnyt ja kokenut elämässään.

Omaksumamme omaelämäkerrallinen opettajatutkimus, jossa sovelletaan jälkistrukturalistista kertomuksen teoriaa (Bruner 1990; Clandinin \& Rosiek 2007; Ricoeur 2005; 1981), edellyttää kuitenkin tekijältään refleksiivisyyttä ja kriittisyyttä omien lähtökohtaolettamusten, havaintojen ja kielen punnitsemiseksi.

Inhimillisen kokemuksen tarkasteluun pääsee vain kertomuksen kautta (Clandinin \& Rieseck 2007; Ricouer 2005), mutta kokemusta ei kuitenkaan "kerätä" tai vapaasti palastella ja sitten teemoittain kursita kokoon elämäkerrallisessa tutkimuksessa. Kysymys on yrityksestä ymmärtää kokemuksessa vastaan tulevia, usein hämmentäviä ja ristiriitaisia asioita. Tällöin se on luonteeltaan juonellistamista eli palasten ja kokonaisuuden hermeneuttista tarkastelua, mutta ei kuitenkaan yhdeksi ehyeksi tarinaksi sovittelua (Clark \& Rossiter 2008; Heikkinen \& Syriälä 2006; Hyvärinen 2010).

Omaelämäkerrallisessa tutkimuksessa lähdemme siitä, että tapahtumien syyt ja seuraukset perustuvat 
ensisijaisesti ihmisten intentioihin. Syy-seuraussuhteet selviävät retrospektiivisesti, kun asiayhteyksien juonelliset, temporaaliset ja sosiaaliset merkitykset tarkentuvat.

Tutkimustavassa ajattelemme, että kertomus voi olla sekä opettajien ammatillisen kasvun että opettajatutkimuksen keskeisin väline (Syrjälä 2015). Tässä tutkija kokee vääjäämättä epävarmuutta, kun hän asettuu kohtaamaan yhtäältä pelkistävän ja formalistisen tutkimusparadigman ja toisaalta kerronnallisen tutkimustavan rajankäynnin, kuten Clandinin ja Connelly (2000) painottavat (ks. myös Heikkinen 2002). Kausaaliset selitykset oppimisesta ja kasvusta osoittautuvat mahdottomiksi, koska niillä ei saavuteta parempaa ymmärrystä.

\section{KERTOMUSTEMME ERILAISUUS}

Yhteisistä opettajuuden lähtökohdista huolimatta omaelämäkerrallisissa tarkasteluissamme tuotimme kaksi erilaista, kummankin opettajan omaa tarinaa. Paljastimme tarinoissamme monia kulttuurisia ja opettajan kasvun ongelmia sekä vaikeiksi koettuja rakenteita (Clandinin \& Connelly 2000). Tällaisten pulmien ja epäkohtien käsittelyn seurauksena toimintaa ja rakenteita voidaan uudistaa.

Liisan väitöstutkimus oli omaelämäkerrallinen opetussuunnitelmatarina (curriculum story, Gudmundsdottir 1990; Clandinin \& Connelly 1988). Molempien tutkijoiden tarkasteluissa ilmeni, miten kehittyvä opettaja toteutti työssään uudistuvia opetussuunnitelmia henkilökohtaisella tavalla jatkuvasti elävässä vuorovaikutuksessa. Opetussuunnitelman toteutumiseen vaikuttivat näin monet sisäiset ja ulkoiset tekijät.

Kertomustemme erilaisuus tulee erilaisista kokemuksista. Toimimme henkilökohtaisilla tavoilla opettajina, tutkimuskohteina ja tutkijoina. Tarkastelimme kokemuksiamme kolmiulotteisen tutkimusavaruuden läpivalaisemana (Clandinin, Pushor \& Murray Orr 2007, 23).

Ulottuvuuksiin kuuluivat kokemuksen ajallinen jatkuvuus, vuorovaikutteisuus ja situationaalisuus. Opettajan työkontekstit vuorovaikutussuhteineen ja ajallisine jatkumoineen ovat aina ainutkertaiset.
Parhaimmillaan omaelämäkerralliset tutkimukset toimivat kehittämisen ja uudistusten käynnistäjinä. Tässä tarkentuu uudelleen omaelämäkerrallisen kertomisen merkitys ja mielekkyys, siis miksi kirjoittaa ja kertoa. Kertomusten jakaminen auttaa luomaan uutta yhteisöllisyyttä. Kertomusten avulla voidaan auttaa toisia näkemään elämäänsä selvemmin, ja muut saattavat ymmärtää kertojia, opettajia, paremmin (Syrjälä 2015).

Kertomuksissamme aikavälit ulottuivat jopa vuosikymmenten taakse. Liisan tarkastelujakso 19792012 oli lähes koko opettajan työuran mittainen. Muuttuneissa kouluissa ja muuttuvan yhteiskunnan kontekstissa uudistuvan opetussuunnitelman merkitys vaihteli kiinteän ja vähemmän kiinteän suhteen väliltä. Luokanopettajaksi kehittyminen ei tapahtunut suoraviivaisesti, vaan se oli ollut monitasoinen ja kompleksinen prosessi.

Eskolla oli lyhyempi tarkastelujakso 2000-2009. Se nosti esiin oppimisen ja kasvun merkityksellisiä haasteita kielenopettajaksi tulemisen kysymyksissä. Pitkä ajanjakso asetti kerronnalle erityisiä haasteita. Tässä tutkimusmateriaalin laatu voi helpottaa tulkintaa, kun siitä suodattuu oleellinen informaatio (ks. Gadamer 2004, 38). Ajallisen etäisyyden mahdollisuutena on toden erottaminen vääristä käsityksistä (Ricoeur 2005, 154). Kertomuksen uskottavuudesta tulee tärkeä kriteeri.

Tutkimusaineistomme olivat hyvin erilaiset. Liisan aineistoon sisältyivät pitkän uran aikaiset opetuksen suunnitelmat eli muun muassa lähes 30000 tuntisuunnitelmaa, koulutyöstä kirjoitetut opettajan pienoistutkielmat sekä päiväkirjat. Liisa koki tällaisen aineiston haasteellisena mutta kerronnan edistyessä myös ehdottomana etuna. Eskon tutkimusaineisto koostui tutkivan opettajan havainnoista, päiväkirjamerkinnöistä ja dokumenteista sekä kollegojen, opiskelijoiden ja työelämän toimijoiden kanssa käydyistä keskusteluista ajalta 2000-2009.

Aineiston analyysi eteni meillä molemmilla (Johnson 2011; Kivioja 2014) kenttätekstin harkintaan perustuneesta valikoinnista välitekstin eli tulkintatekstin kirjoittamiseen. Tämä tarkoitti juonellistavaa kirjoittamista ja kertomista. Liisa tuotti tulkintanäköaloja muun muassa henkilökohtaisesta suunnitteluai- 
neistostaan ja Esko vastaavasti opettajantyön dokumenteistaan samoin kriittisesti punniten. Tämän jälkeen oli vuorossa tutkimustekstin esiin nostaminen, kenttätekstien ja välitekstien tuomista näköaloista. (Clandinin \& Connelly 2000). Itseymmärrys oli jatkuvaa tulkintaa. Tässä hermeneuttisuus tarkoitti itseymmärryksen reflektoivaa kehittämistä ja sen kuulumista opettajan kehittymisprosessiin.

Eskon tutkimuksen tehtävänä oli kielenopettajan oppimisen ja kasvun autobiografinen tarkastelu (Johnson 2011). Tutkimuksessa avautui näkökulma kielenopettajaksi kehittymiseen ammattikorkeakoulun kielenopetuksen piirissä. Tutkimuskysymyksen asettelua ohjasi tarve tutkia, miten hän oppi ja kehittyi ammatillisesti. Hän käsitteli aineistonsa uudelleenluennan, toisin sanoen edellä mainitun analyysin sekä metafora-analyysin eli kielikuvien tulkinnan avulla (Cameron 2003). Ajassa etenevä, paikkaan ja kontekstiin sijoittuva opetustyön kehittäminen teki ilmeiseksi opettajan oppimisen ja kasvun. Näissä haasteissa Esko saattoi tutkivana opettajana löytää itsensä ja nähdä, mitä ja miten hän oli oppinut.

Havaitsimme, miten erilaiset tutkimusaineistot ovat vaikuttaneet tarinoidemme sisältöihin erilaisissa tulkintakonteksteissa. Tutkijan työskentelyssämme painottui autobiografiselle lähestymistavalle ominainen jatkuvasti haastava kriittisyys ja refleksiivisyys. Itsen lisäksi myös aineistoa tuli tarkastella kriittisesti monista näkökulmista. Tutkimuksen esiin tuomia näkökulmia tuli kyseenalaistaa (Töttö 2004, 138).

\section{MITEN NIIN "OTTAA JA ANTAA"?}

Jos tutkiva opettaja on kiinnostunut teoretisoinnista sekä tutkimuksen tuottamista detaljeista ja niiden analyysista enemmän kuin laajoista kysymyksenasetteluista, avoimesta tutkimusasetelmasta ja oman tutkijakokemuksensa kertomisesta, omaelämäkerrallinen tutkimustapa on tuskin hänelle sopiva tutkimisen tapa. Samoin mikäli tiedonkeruumenetelmien ja analyysitapojen kehittely sekä tutkimustulosten vertailu ja yleistettävyys ovat hänelle tärkeämpiä kuin tutkijakokemuksen käsittely tietoteoreettisine haasteineen, emme voi ehkä suositella hänelle omaelämäkerrallista (opettaja)tutkimusta.
Autobiografia mahdollistaa oman, persoonallisen elämänkulun kirjoittamisen. Kertomalla kokemuksistamme tuotamme ja välitämme todellisuutta, ja tässä kielellä on merkittävä asema (Ricoeur 2005; Spector-Mersel 2010, 11). Vaikka kertomuksemme imitoivat elämää, emme voineet jäljentää koko elämän todellisuutta. Saatoimme tuottaa vain yhden tarinan monista mahdollisuuksista. Pyrimme tuottamaan todentuntuiset tarinat. Tuotimme myös narratiivista tietoa. Tällaisella omaelämäkerrallisella, narratiivisella tiedolla ja tietämisellä on paikkansa tiedemaailmassa (Bruner 1986, 10-11; Polkinghorne 1995). Paradigmaattisen tiedon kanssa ne täydentävät toisiaan, mutta ne eivät sulaudu toisiinsa.

Omaelämäkerrallisten tutkimusten vahvuutena on kiistatta subjektiivisuus, henkilökohtaisuus ja paikallisuus (Bernhardt 2009; Clandinin \& Connelly 2000; Freeman 2007). Lähestymistavan antina on parempi ymmärrys itsestämme opettajina ja toiminnoistamme. Hyödyn ymmärtäminen laajemmin liittyy kontekstoituneisiin tarinoihimme. $\mathrm{Ne}$ kytkeytyvät erityisesti suomalaiseen opetus- ja kasvatuskulttuuriin, koulutuspolitiikkaan sekä opettajan työn historiaan. Yksilöllisen opettajan työ voidaan nähdä mikrotason tarinana. Sen sijaan esimerkiksi opettajan työssään käyttämä ja vahvasti yhteiskuntaan kytkeytyvä opetussuunnitelma edustaa makrotason tarinaa.

Tutkimuksissamme kerromme tarinat niiden kulttuurisissa, sosiaalisissa ja historiallisissa yhteyksissä. Tämän vuoksi ne eivät ole ajallisesta etäisyydestään huolimatta vain "irrallisia" henkilökohtaisia tarinoita, vaan tuottavat perspektiivejä ja opettavat muillekin elämästä ja (luokanopettajan ja kielenopettajan) työstä - sekä tavoiteltavia että vältettäviä asioita. Tarina eli kerrottu kertomus on peili, josta voi heijastua vastauksia toiselle henkilölle hänen omaan elämäntilanteeseensa. Narratiivinen reflektio palauttaa mieleen ja "pelastaa" tuntemattomiksi jääneiltä kokemuksilta ja inhimilliseltä unohtamiselta. Tarinat antavat näin tilaa reflektioavaruudelle ja ovat kiinteä osa tutkittua elämää. (Freeman 2007, 162.)

Omaelämäkerrallinen tutkija asettaa myös itsensä ja toimintansa tarinana tiedemaailman lukijoiden arvosteltavaksi ja arvioitavaksi. Autobiografisissa tut- 
kimuksissamme korostuu herkällä tavalla henkilökohtaisuus. Itsestä on annettava jotakin henkilökohtaista, mitä tutkija kohteena ollessaan on kokenut,. Omakohtaisen aineiston käsittely herättää erilaisia tuntemuksia, myös kielteisiä, vieläpä traumaattisia muistoja. Tutkija joutuu tasapainoilemaan liian henkilökohtaiselle alueelle etenemisen vuoksi. Eettisesti ajatellen itsen paljastumisen määrittämisessä on säilytettävä tarinan aitous. (Bernhardt 2009, 66.)

Brunerin (2002) mukaan autobiografia tekee tottuneestakin kirjoittajasta kaksoisolennon. Kertoja joutuu omaelämäkertaa kirjoittaessaan hakemaan tasapainoa sen välillä, mitä hän oli ja toisaalta mitä hän olisi voinut olla. Samalla tavalla hän joutuu pohtimaan, mitä hän teki ja olisi voinut tehdä. Nämä kysymykset vievät pitkiin mietteisiin, mikä on ehkä elämäkerrallisen tutkimisen ja kirjoittamisen parasta antia.

Olemme molemmat eri tavoin kokeneet, että omaelämäkerralliseksi tutkijaksi kehitytään pitkäjännitteisen työn kautta. Omasta opettajan kokemuksista kirjoittaminen voi olla monessa suhteessa vaativampaa kuin esimerkiksi määrällisen tai laadullisen aineiston kerääminen, analyysi ja tulkinta. Tutkijaksi kasvussamme joutuivat oman persoonan lisäksi monet opettajan työtä, elämää, todellisuutta ja tutkimusta koskevat perusolettamuksemme uuteen tarkasteluun. Se ei kuitenkaan ollut mikään peruuttamaton tai rajoittava muutosprosessi vaan rikasti opettajuutta ja tutkijuutta sekä kehitti tutkijan taitoja. Erilaisten tutkimustapojen ja -paradigmojen ymmärtäminen on meille tänään ehkä helpompaa ja luontevampaa kuin omaelämäkerrallista tutkimusta aloittaessamme.

Tässä puheenvuorossa kuvaamamme tutkimisen tapa - joka ei ole pelkästään menetelmä - voi tehdä tutkivan opettajan työstä antoisan ja vapauttavan, vaikka monikerroksisuuden ja monien uusien merkitysten vuoksi samalla myös epävarman. Olemme pyrkineet osoittamaan, miten omaelämäkerrallinen opettajatutkimus ottaa ja antaa. Elämä, toiminta ja kokemus vaativat kerrotuksi tulemista ja kertominen vastaavasti työtä, itsensä likoon laittamista. Tutkimus, joka tunnustaa ihmisen ainutkertaisuuden ja suhteessa olemisen, avaa uusia näkymiä opettajan ammatilliseen oppimiseen ja kasvuun.

Esko Johnson

KT

filosofinen tiedekunta

Itä-Suomen yliopisto

Liisa Kivioja

KT

kasvatustieteiden tiedekunta

Jyväskylän yliopisto 
Bernhardt, P. (2009). Opening Up Classroom Space: Student voice, Autobiography \& the Curriculum. The High School Journal. The University of North Carolina Press 92(2), 61-67.

Bruner, J. (2002). Making stories. Law, literature, life. Cambridge, MA: Harvard University Press.

Bruner, J. (1990). Acts of Meaning. Cambridge, MA: Harvard University Press.

Bruner, J. (1986). Actual minds, possible words. Cambridge, MA: Harvard University Press.

Cameron, L. (2003). Metaphor analysis in educational discourse. London: Continuum.

Clandinin, D. \& Connelly, F. (1988). Teachers as curriculum planners: Narratives of experience. New York: Teachers College Press.

Clandinin, D. \& Connelly, F. (2000). Narrative Inquiry: Experience and Story in Qualitative Research. San Franciso, CA: Jossey-Bass.

Clandinin, D., Pushor, D. \& Murray Orr, A. (2007). Navigating Sites for Narrative Inquiry. Journal of Teacher Education 58(1), 20-35.

Clandinin, D., \& Rosiek, J. (2007). Mapping a landscape of narrative inquiry. Teoksessa Clandinin, D. (toim.) Handbook of narrative inquiry: Mapping a methodology. Thousand Oaks: CA, 35-75.

Clark, M. \& Rossiter, M. (2008). Narrative learning in adulthood. Teoksessa S. Merriam (toim.) Third Update on Adult Learning Theory. New Directions in Adult and Continuing Education no. 119. San Francisco, CA: Jossey-Bass, 61-71.

Freeman, M. (2007). Life "on holiday"? In defence of big stories. Teoksessa Bamberg, M. (toim.) Narrative - state of the art. Amsterdam: Benjamins, 155-164.

Gadamer, H. (2004). Hermeneutiikka. Ymmärtäminen tieteissä ja filosofiassa. Suom. I. Nikander. Tampere: Vastapaino.

Gudmundsdottir, S. (1990). Curriculum Stories: Four Case Studies of Social Studies Teaching. Teoksessa Day, C., Pope, M. \& Denicolo, P. (toim.) Insight into Teachers' Thinking and Practice. London: Falmer, 107-118.

Heikkinen, H.L.T. (2002). Whatever is Narrative Research? Teoksessa Huttunen, R. Heikkinen, $\mathrm{H}$. \& Syrjälä, L. (toim.) Narrative Research. Voices of Teachers and Philosophers. Jyväskylä: SoPhi, 13-28.
Heikkinen, H.L.T. \& Syrjälä, L. (2006). Tutkimuksen arviointi. Teoksessa Heikkinen, H.L.T., Rovio, E. \& Syrjälä, L. (toim.) Toiminnasta tietoon. Toimintatutkimuksen menetelmät ja lähestysmistavat. Helsinki: Kansanvalistusseura, 144-162.

Hyvärinen M. (2010). Eletty kertomus ja luonnollinen narratologia. Teoksessa Hatavara, M., Lehtimäki, M., \& Tammi, P. (toim.) Luonnolliset ja luonnottomat kertomukset. Jälkiklassisen narratologian suuntia. Helsinki: Gaudeamus, 131-157.

Johnson, E. \& Kivioja, L. (2016). Oma kertomus elää muuttuvassa maailmassa. Kokemuksia autobiografisesta opettajatutkimuksesta. Ammattikasvatuksen aikakauskirja 1/2016, 62-71.

Johnson, E. (2011). Kielenopettajaksi tuleminen ammattikorkeakoulun muutosmaisemassa $A$ : Tutkimusraportteja - Forskningsrapporter. KeskiPohjanmaan ammattikorkeakoulu.

Kivioja, L. (2014). Opetussuunnitelman opettelijasta pohtivaksi osaajaksi. Omaelämäkerrallinen opetussuunnitelmatarina. Kasvatustieteen väitöskirja. Jyväskylän yliopisto. Kokkolan yliopistokeskus Chydenius.

Polkinghorne, D. (1995). Narrative configuration in qualitative analysis. Teoksessa Hatch, J. (toim.) Life history and narrative. London: Routledge.

Ricoeur, P. (2005). Mimesis, viittaus ja uudelleenhahmottuminen. Suomennos J. Tontti. Teoksessa J. Tontti (toim.) Tulkinnasta toiseen. Esseitä hermeneutiikasta. Tampere: Vastapaino, 164-174.

Ricoeur, P. (1981). Hermeneutics and the human sciences. Toimittanut ja kääntänyt J. Thompson. Cambridge: Cambridge University Press.

Spector-Mersel, G. (2010). Narrative research. Time for a paradigm. Narrative Inquiry 20(1), 204-224.

Syrjälä, L. (2015). Elämäkerrat ja tarinat tutkimuksessa. Teoksessa Aaltola, J. \& Valli, R. (toim.) Ikkunoita tutkimusmetodeihin I. Metodin valinta ja aineiston keruu: virikkeitä aloittelevalle tutkijalle (2. p.). Jyväskylä: PS-kustannus 257-270.

Töttö, P. (2004). Syvällistä ja pinnallista. Teoria, empiria ja kausaalisuus sosiaalitutkimuksessa. Tampere: Vastapaino. 